\title{
Estimation of river flood damages in Jakarta, Indonesia
}

\author{
Pini Wijayanti ${ }^{1,2} \cdot$ Xueqin Zhu $^{1} \cdot$ Petra Hellegers $^{1} \cdot$ \\ Yus Budiyono $^{3,4} \cdot$ Ekko C. van Ierland $^{1}$
}

Received: 26 June 2015/ Accepted: 9 December 2016/Published online: 20 December 2016

(C) The Author(s) 2016. This article is published with open access at Springerlink.com

\begin{abstract}
Flooding is a serious problem in Jakarta, and detailed estimation of flood damage is necessary to design optimal flood management strategies. This study aims to estimate flood damage in a densely populated area in Jakarta by means of a survey, to develop the relationship between flood characteristics and flood damage, and to compare the damage estimates from the survey with the damage estimates obtained by a flood damage model for Jakarta, i.e. the damage scanner model. We collected data on economic losses of the January 2013 flood in a survey of flood-affected households and business units in Pesanggrahan River. The actual flood damage in the survey area is US\$ 0.5 million for the residential sector and US\$ 0.7 million for the business sector. The flood damage for a similar event in the same area based on the damage scanner model is estimated to be US\$ 1.3 million for the residential sector and US\$ 9.2 million for the business sector. The flood damage estimates obtained by the survey approach are lower compared to the damage scanner approach due to different ways in obtaining flood damage data and in defining the maximum flood damage per object, the different spatial levels of analysis, and uncertainties in constructing the flood damage curves that were applied in the damage scanner model.
\end{abstract}

Keywords Flood damage $\cdot$ Survey $\cdot$ Damage scanner $\cdot$ Jakarta

Pini Wijayanti

pini.wijayanti@wur.nl

1 Environmental Economics and Natural Resources Group, Wageningen University, Wageningen, The Netherlands

2 Bogor Agricultural University, Bogor, Indonesia

3 Institute for Environmental Studies, VU University, Amsterdam, The Netherlands

4 Agency for the Assessment and Application of Technology, Jakarta, Indonesia 


\section{Introduction}

Jakarta, the capital city of Indonesia, has been regarded as one of the world's most vulnerable cities with regard to climate change-related disasters. The city is prone to flooding, not only because of precipitation, but also as a result of soil subsidence, increasing sea level, and natural calamities (Firman et al. 2011). Over the past two decades, Jakarta was hit by major floods in 1996, 2002, 2007, and 2013. The 2007 flood was regarded as a national disaster, which caused a total loss of US\$ 565 million. ${ }^{1}$ The residential sector suffered most with 74\% of total losses (BAPPENAS 2007). Excessive rain in Jakarta and surrounding cities caused a major flood from 17 to 19 January 2013, which inundated 124 villages in Jakarta Province with 98,000 houses, displaced 40,000 people, and killed 20 people. The flood caused in total an estimated damage of US\$ 775 million $^{2}$ (BPBD 2013). These events show that flooding is a serious problem in Jakarta.

The ability to assess flood damage is the key in developing effective flood policies and implementing flood protection measures to reduce expected flood damages (Green 2003; Mays 2011). Therefore, an accurate flood damage assessment is crucial for effective and efficient flood risk management (Middelmann-Fernandes 2010).

The government of Jakarta conducted flood damage assessments following the 2007 and 2013 floods by using the damage and loss assessment methodology of the Economic Commission for Latin America and the Caribbean. Besides the assessment of ex-post flood events, several studies estimated the future coastal flood and river flood damages in Jakarta (e.g. PU 2011; Ward et al. 2011b). These studies, however, cover the whole Jakarta area and do not provide the detailed information that survey data of specific flooded areas provide. As detailed information is important in presenting the local flood situation and in evaluating the cost-effectiveness of flood measures for stakeholders, a detailed flood damage assessment for a specific area is needed.

The aims of this paper are (1) to provide insight into the level of the flood damages; (2) to estimate the relation between flood damage and flood characteristics; and (3) to compare the results of two different approaches. The following three research questions are addressed: What is the flood damage in the residential sector and the business sector? How is this related to flood characteristics? And Are the results comparable to the results obtained by the damage scanner model for a similar flood event for the relevant area?

This paper is organized as follows. Section 2 presents a literature review on flood damage assessment. Section 3 provides the methodology of this study, where the flood damage function is specified. Section 4 gives the results of the estimated flood damage from the survey and compares the results with the experts' assessment through the damage scanner model. Section 5 contains the discussion and conclusions.

\section{Some concepts and approaches used in the literature}

Previous studies have distinguished several types of flood damage. First, there are direct damages and indirect damages. The former refers to damages caused by the physical contact of flood with humans, property, or any other objects, while the latter implies indirect damages, either caused by the flood impact or occurring after the flood event

\footnotetext{
1 We express values in US\$ of January 2007, using an average exchange rate of US\$ $1=$ IDR 9125.

${ }^{2}$ We express values in US\$ of January 2013, using an average exchange rate of US\$ $1=$ IDR 9735.5.
} 
(Merz et al. 2010). Second, based on the ability to assess damages in monetary terms, these damages are categorized into tangible and intangible damages. Tangible damages mean the damages that can be valued in monetary terms, e.g. damages to buildings and contents, while intangible damages are difficult to be expressed in monetary terms, e.g. loss of life and trauma (Jonkman et al. 2008; Merz et al. 2010). Most studies only estimated direct tangible damages (see Gissing and Blong 2004; Kreibich et al. 2010), because the estimation of intangible damages is difficult.

Flood damage is often classified into actual and potential damage (Smith 1981). The former refers to the damage resulting from a particular flood event (Gissing and Blong 2004), while the latter estimates maximum possible damage, which may occur if an area without any flood protection measures becomes inundated (Messner and Meyer 2007). In addition, expected damage refers to flood risk (Gartsman et al. 2009), which is the product of the probability of flooding (which is defined as "the probability that floods of a given intensity and a given loss will occur in a certain area within a specified time period" (Merz et al. 2007, p.238)) and the damages when a flood occurs.

The spatial boundaries of a flood damage assessment influence its result (Merz et al. 2010). Based on a spatial approach, flood damage assessment can be conducted at the micro-, meso-, and macro-scales, which are estimates of the damage at the object level, land-use category, and municipal level, respectively (Messner and Meyer 2007).

Most studies estimate flood damage using damage functions, which connect the damages to particular elements at risk with the flood characteristics (Merz et al. 2010). The element at risk represents the number of social, economic, or ecological units, which are affected by flood hazard in a particular area, i.e. people, households, companies, and infrastructures, while the flood characteristics include its depth, duration, velocity, and contamination (Messner and Meyer 2007). Thieken et al. (2005) use impact and resistance factors in determining flood damage to buildings. The impact factors are similar to flood characteristics, while resistance factors are the resistance condition of the building to flood, which can be temporary (e.g. due to flood warning and preparedness) or permanent (e.g. due to building material and precautionary measures).

A flood damage function can be developed by using empirical and synthetic approaches (Merz et al. 2010). The empirical approach implies using data gathered following a particular flood event, while the synthetic approach uses data collected through "what-ifquestions", i.e. the amount of expected damage in case of a certain flood condition (Merz et al. 2010; Thieken et al. 2005). However, a synthetic approach involves trade-offs between required time and precision, because it relies on fictional scenarios from which information is derived (Smith 1994).

Previous studies developed flood damage functions by relating the direct flood damage to flood depth (see Jonkman et al. 2008; Kazama et al. 2010; Scawthorn et al. 2006; Suriya et al. 2012). Such a function is called a stage-damage function or depth-damage function. Meanwhile, other studies add other parameters, such as flood duration (e.g. Dutta et al. 2003; Tang et al. 1992), velocity (Thieken et al. 2005), and contamination (Kreibich et al. 2010). The two steps to analyse flood damage include determining the impact factors or the exposure indicators, e.g. depth and duration, and assessing the damage in monetary terms (Messner and Meyer 2007). 


\section{Methodology}

We conducted surveys on households and business units from April to June 2013 to obtain information on flood damage, flood characteristics, and socio-economics characteristics, based on the 17-19 January 2013 flood event. Based on those data, we used regression analysis to develop flood damage functions to know how flood characteristics are related to the damage. Finally, we compared the flood damage obtained from the survey with the estimated flood damage obtained by using the damage scanner model of Jakarta for the relevant area.

\subsection{Study area}

Our survey focused on the residential and business areas along the Pesanggrahan River (see Fig. 1). For the business sector, the survey also covered some parts of the Angke River in West Jakarta.

We conducted the survey in two municipalities: South Jakarta and West Jakarta. Figure 1 shows our study area, which extends from south to northwest Jakarta. The study area covers six villages with a total area of $12.3 \mathrm{~km}^{2}$. In South Jakarta, the survey included Pesanggrahan and Kebayoran Lama Districts and covered three villages, i.e. Ulujami, Kebayoran Lama Utara, and Cipulir. While in West Jakarta, it included Kebun Jeruk and Cengkareng Districts and covered three villages, i.e. Kedoya Selatan, Sukabumi Selatan, and Rawa Buaya.

Those villages are densely populated areas, and most of the population lives in slums and works in the informal sector. During 2013, at least seven episodes of flooding on different scales occurred in these areas. The January 2013 flooding was caused by a heavy rainstorm, which resulted in the overflowing of the Angke and the Pesanggrahan Rivers (Deltares 2013) and inundated 1706 houses in those villages.

\subsection{Sampling methods}

Samples were selected by using a two-stage sampling method. First, villages along the river were listed and the number of flooded neighbourhoods within villages was identified. Second, the neighbourhoods for the survey were selected by purposive sampling. Household samples were then selected in various neighbourhoods by using simple random sampling. The total number of samples was about 300 households and 150 businesses.

Households and business units were eligible for the survey if they had been affected by the flood and had suffered from economic, health, and/or physical damages. The contact person at the household level was the head of household, while the contact person for businesses was the owner or the manager. If a contact person was not eligible or inhabited at the time of the survey, the next closest household or business unit was approached.

\subsection{Model specification to develop flood damage function}

We employed a micro-scale approach to assess damages in the residential and business sectors. The flood damage function was estimated empirically. In our model, the flood damage was explained by two types of factors, i.e. flood impact factors (or flood characteristics) and socio-economic factors. The first set of factors consist of depth, duration, and distance from buildings to a river. The depth is the over-floor depth of the flood, while 


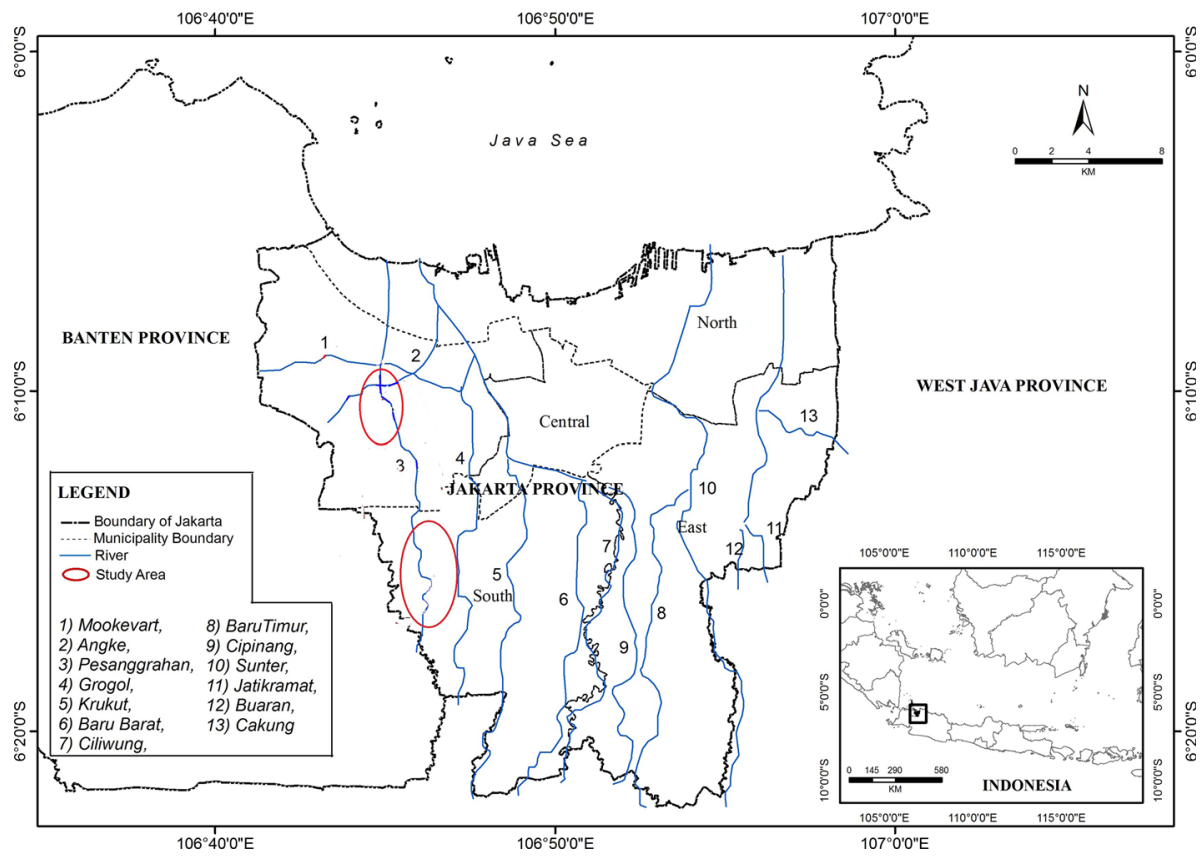

Fig. 1 Map of Jakarta indicating the study area

the duration indicates the length of time that the water stays inside the buildings. The second set of factors include the income of the sector and the surface area of the building. For the residential sector, income was represented by monthly income of households, while the business sector was represented by monthly turnover. The surface area indicates how many square metres of the living area owns by each building.

We developed the flood damage function to indicate the economic relationship between actual flood damage (AFD) as a dependent variable, and flood characteristics and socioeconomic factors as independent variables. Because data collected by the survey are not normally distributed, we tested several methods for regressions analysis and considered several alternative combinations of variables and functional forms, e.g. linear, log-linear, double log, and quadratic, by including and excluding the constant. Finally, we applied the linear functional form, which gave the best results in terms of statistical significance:

$$
\mathrm{AFD}_{i}=\beta_{0}+\beta_{1} \mathrm{DEP}_{i}+\beta_{2} \mathrm{DUR}_{i}+\beta_{3} \mathrm{DIS}_{i}+\beta_{4} \mathrm{INC}_{i}+\beta_{5} \mathrm{ARE}_{i}+\varepsilon_{i}
$$

where $\mathrm{AFD}_{i}$, actual flood damage (IDR thousand) of respondent $i$; $\mathrm{DEP}_{i}$, flood depth $(\mathrm{cm})$ inside building of respondent $i$; $\mathrm{DUR}_{i}$, flood duration (h) inside building of respondent $i$; $\mathrm{DIS}_{i}$, distance from a river to the building (or housing) (m) of respondent $i$; $\mathrm{INC}_{i}$, income (IDR thousand/month) of respondent $i$; $\mathrm{ARE}_{i}$ : building (or housing) area $\left(\mathrm{m}^{2}\right)$ of respondent $i$; $\varepsilon_{i}$, error term.

The dependent variable AFD covered the direct and indirect tangible damage. The direct damage included building structure damage and building content damage. The content meant the detailed inventories of the physical objects inside and outside the buildings. To estimate the building structure damage, we used replacement value, while to assess the building contents, we used depreciated value with a depreciation rate of $1 \%$ per 
year. The indirect damage in the residential sector included clean-up costs, loss of income, costs related to evacuation, and health-related costs during the flood. Meanwhile, for the business sector, the indirect damage costs were approximated by the loss of turnover during the flood, because detailed information on profit loss could not be obtained as business men are unwilling to report about profits.

The loss of income of households was calculated by multiplying the number of days missed at work due to flooding with the daily income. The costs of evacuation and temporary accommodation were the sum of the total costs for travel, food, and lodging due to evacuation. The cost due to illness is equal to the costs of visiting a doctor, staying in hospital, and buying the medicines required following a flood.

For the given obtained samples, we estimated the flood damage function by the ordinary least squares (OLS) estimator. The OLS produces unbiased and efficient estimated coefficients in the linear model (Greene 2012; Verbeek 2012). Based on Eq. (1), the null hypothesis is that each coefficient has no effect on the expected AFD. We tested the hypothesis by means of $t$ tests and $F$ tests, and we report $R$-square $\left(R^{2}\right)$. In order to detect multicollinearity and homoscedasticity, we used the variance inflation factor (VIF) value and white test, respectively. Having the estimated coefficients and corresponding standard errors, we interpreted the results and used the model to estimate the annual AFD. The observed data were analysed using software STATA 10.

\subsection{Damage scanner model}

The damage scanner model has three major inputs, i.e. (1) flood hazard, represented by the inundation depth and extent map, (2) flood exposure, represented by the land-use value, and (3) flood vulnerability, represented by the depth-damage curve (te Linde et al. 2011). The damage scanner has been described in several studies (te Linde et al. 2011; Ward et al. 2011a). This study employed the damage scanner model for Jakarta developed by Budiyono et al. (2015), which used Python programming, particularly Numpy and GDAL libraries to produce the flood risk maps and CorelPolyGUI add-ons on LibreOffice Calc to plot the exceedance probability.

To estimate flood damage in the survey areas by the damage scanner, the initial step is to know the return period of rainfall that occurred from 15 to 18 January 2013. The return period is the expected value of the recurrence interval (time between occurrences) of rainfall events of the same magnitude (Mays 2011). The daily rainfall intensity during four days was recorded in the Pondok Betung weather station managed by the Indonesian agency for meteorology, climatology, and geophysics (BMKG). The sum of those rainfall data produced the accumulated rainfall intensity that was used to indicate the return period of the flood. BMKG provides the calculation of the accumulated rainfall intensity (extreme rainfall) for various return periods from 2 to 100 years, based on the generalized extreme value (GEV) method by employing rainfall data from 1981 to 2010 (Table 1).

Table 1 Extreme rainfall and its return period in Pondok Betung station, Jakarta, from 1981 to 2010 with GEV method Source: BMKG and KNMI (2013)

\begin{tabular}{llllllll}
\hline Return period & 2-year & 5-year & 10-year & 20-year & 25-year & 50-year & 100 -year \\
\hline Rainfall (mm/day) & 116.6 & 156.9 & 190.6 & 229.4 & 243.2 & 291.1 & 347.6 \\
\hline
\end{tabular}


The flood hazard map was acquired from the Flood Hazard Mapping (FHM) project conducted by Deltares in 2012. It was produced by using the one-dimensional hydraulic module (1D) and two-dimensional hydraulic module (2D) of the SOBEK hydrology model to study the hazard over the greater Jakarta catchment, including the Pesanggrahan River. The 1D simulates one-dimensional flow (i.e. water level and discharges) through the main rivers and the main drainage system, and 2D simulates the inundation pattern over the project area from the locations where the 1D water courses are overtopped (Deltares 2012). Inputs to the model characterize the 2007 flood occurrence. The hazard map acquired from FHM has not been validated on the event from the survey data, because the FHM used data obtained before January 2013.

The information on flood exposure, i.e. the value of assets that are exposed to flood, was gathered from a previous study conducted by Budiyono et al. (2015). To compare the damage scanner results with the survey results, we focused on only two land-use classes, i.e. the high-density urban village (representing the residential sector), and the commercial and business area (representing the business sector). An expert workshop, which involved experts consisting of representatives from government agencies, public organizations, and businesses, was organized to estimate the maximum extent of damages created for each land-use class.

The vulnerability curves indicate the percentage of damage that would occur at different flood depths in each land-use class (Merz et al. 2010). Here, the curves were developed in the workshop by using a synthetic stage-damage curve through "what-if-questions" on each land-use class at incremental $25 \mathrm{~cm}$ depths up to maximum inundation depth of $200 \mathrm{~cm}$. Prior to discussion, a description on the possible structure and assets was delivered to the experts to give an overview on the assets exposed to flooding. Furthermore, experts from related fields discussed the land-use class groups to reach a consensus on the damages and losses for various scenarios of depth.

\section{Results}

In Sects. 4.1, 4.2, and 4.3, we present the descriptive statistics of the damage data set, the actual flood damage based on the collected data from survey, and the relationship between flood damage and the flood characteristics as obtained in our regression analysis of the survey data. Finally, Sect. 4.4 compares the results of the flood damage estimates obtained from the survey with flood damage estimates for the relevant area based on the damage scanner model.

\subsection{Descriptive statistics}

Household included in the survey were living, on average, $84.8 \mathrm{~m}$ away from the river, with a maximum distance of $284 \mathrm{~m}$. Their houses were mostly permanent constructions with a total area of less than $70 \mathrm{~m}^{2}$, on average. Half the respondents lived in one-storey houses and half in two-storey houses. The second floor was deliberately built as an adaptation mechanism to flooding. Their monthly income in 2013 was on average of US\$ 344 , and $42 \%$ received monthly income below the standard regional minimum income, which is US\$226. The majority of livelihoods of local people are mostly in the informal sector, and $36 \%$ of respondents claimed they earned a living from running small 
businesses. From April 2012 to April 2013, 53\% respondents experienced 6-15 flood events. During the January 2013 flood, there was on average $87 \mathrm{~cm}$ of water in the house for $98 \mathrm{~h}$.

Most of the business units were in charge of small- to medium-scale enterprises, e.g. small shops, groceries, cloth shops, and small restaurants. About $81 \%$ respondents employed one to four workers, and about $75 \%$ had less than US\$205 business daily turnover. Most businesses occupied small buildings to run their activities. On average, the area including the garage was $38 \mathrm{~m}^{2}$. Not all buildings had a basement, and $87 \%$ were permanent buildings. About $72 \%$ had an attic, and $13 \%$ had a garage or carport. Buildings were located, on average, $84.8 \mathrm{~m}$ away from the river, up to $123.7 \mathrm{~m}$ away from the river. About $51 \%$ of business activity took place in their buildings. From April 2012 to April $2013,45 \%$ of respondents experienced 6-15 flooding events. After the January flood, three flood events occurred in the survey areas; however, the magnitude of those events was small and did not cause significant losses. During the January 2013 flood, the average inundation depth was $74 \mathrm{~cm}$ and there was water in the buildings for $84 \mathrm{~h}$.

\subsection{The actual flood damage}

For the residential sector, the average flood damage per household was US\$ 308. Households with more property at risk, such as vehicles and electronics, experienced the highest flood damages. For most households, the direct damage was greater than the indirect one. Table 2 indicates that the content damage was the major component of losses.

The content losses varied across households from zero to an estimated US\$ 863 . The zero value is obtained in the very poor households, which have limited household stuffs. The higher losses were found in households with higher family income and larger houses. Households who owned a two-storey house could safely store their assets on a higher floor; hence, they could minimize the losses. After the flooding episode, households spent on average $24 \mathrm{~h}$ or three person-days to clear their houses of mud and to tidy up the house contents. The average number of days missed from work was four, and the income loss per household during those days varied from zero to US\$ 359.

About $70 \%$ of the respondents moved to temporary places such as family houses, mosques, or evacuation camps because they were evacuated or their homes needed repair as a result of the flood. On average, they stayed in temporary shelters for about five to six days and spent about US\$ 12 per day for travelling, food, water, and lodging.

Table 2 Average actual flood damage per household for the 17-19 January 2013 flood event

\begin{tabular}{lcc}
\hline Damage & Value (US\$) & Percentage $(\%)$ \\
\hline 1 Direct & & 14 \\
1a Structural damage & 43 & 63 \\
1b Content damage (inside and outside) & 193 & 8 \\
2 Indirect & 25 & 10 \\
2a Clean-up cost & 30 & 4 \\
2b Loss of income & 12 & 2 \\
2c Evacuation and temporary house & 5 & 100 \\
2d Cost of illnesses & 308 & \\
Total & & \\
\hline
\end{tabular}


Regarding the cost of illnesses, the number of family members who suffered from several diseases during and after the flood event varied from one to three people per house and most of them were children. They suffered from fever (34\%), skin irritation (21\%), and diarrhoea (18\%). Although $89 \%$ visited a doctor, the average cost of illnesses was low for each household (not for society) because $45 \%$ visited doctors provided by the government or social organizations, which those are provided freely. Theoretically the freely provided assistance should also be counted in the costs; however, due to untraceable information this was not possible in practice. To what extent the cost of illness is due to the flood is not clear. However, the damages related to the cost of illness are relatively low, and if only a share of these damages is attributed to the flood event, the overall results would not change substantially.

For the business sector, the average flood damage per business unit was US\$ 854. About $12 \%$ of the respondents had flood damage less than US\$ 154 , and $10 \%$ of the respondents had flood damage in excess of US\$2054. Business units with more items in their properties experienced a higher flood loss.

For most business units, the total indirect damage was greater than the total direct damage. Total direct damages including structural and contents damages were US\$216, whereas total indirect damages including turnover loss, temporary premises cost, labour cost, and clean-up cost were US\$ 638 .

In the direct costs, the structural damage was less than content damage because most owners had small buildings. Content damage was quite high, and it showed that the owners did not have enough time to evacuate their contents. Table 3 shows that the highest cost was the turnover loss, which depends on the number of days the businesses had to close due to flooding. About $93 \%$ of the respondents closed their business due to flooding with an average five-day closure. Nevertheless, only $4 \%$ of businesses set up temporary headquarters at another location.

\subsection{Analysis of the relationship between flood characteristics and flood damage}

\subsubsection{Residential sector}

The flood damage function in the residential sector produces the results given in Table 7 in "Appendix". The function has $R^{2} 0.26$, and this means $26 \%$ of the variation in household AFD can be attributed to the five exogenous variables. DEP, DUR, INC, and ARE have

Table 3 Average actual flood damage per business unit for the 17-19 January 2013 flood event

\begin{tabular}{lcc}
\hline Damage & Value (US\$) & Percentage \\
\hline 1 Direct & & 7 \\
1a Structural damage & 58 & 19 \\
1b Content damage & 158 & \\
2 Indirect & & 63 \\
2a Turnover loss & 540 & 2 \\
2b Temporary quarters & 17 & 5 \\
2c Labour cost & 40 & 5 \\
2d Clean-up cost & 41 & 100 \\
Total & 854 & \\
\hline
\end{tabular}


$p$ values lower than 0.05 . We therefore reject the null hypothesis that those variables have no effect on AFD and show that those variables are good predictors of AFD. Our hypothesis was that the distance to the river (DIS) would have a negative sign. However, in the regression analysis it shows a positive sign. This might occur since households living close to the river have already taken precautionary actions, e.g. increasing floor height and constructing concrete walls in front of their houses. Furthermore, in some areas, the elevation area located close to the river is higher than that further away from the river; in that case, the overflowing water goes to the lower areas.

All coefficients have positive signs, which indicate that the change in an independent variable will increase the expected AFD, ceteris paribus. For example, increasing one additional centimetre on the flood depth will increase the expected damage by IDR 13, 040 (US\$ 1.3), ceteris paribus. The $F$-statistic takes the value of 20.25 , the appropriate $5 \%$ critical value being 2.10, which implies that the joint hypothesis of all coefficients being zero has to be rejected. All VIF values for five independent variables are less than 10, meaning that there is no multicollinearity or no correlation between $\varepsilon_{i}$ and the independent variables. Moreover, this also indicates that the linear relationship among the independent variables leads to reliable regression estimates (Verbeek 2012). However, we rejected the null hypothesis of homoscedasticity because the $\mathrm{NR}^{2}(76.83)$ is higher than $\chi^{2}(5)$ at $5 \%$ significant level (9.49). This indicates that heteroscedasticity is present in the model. Results from multicollinearity and homoscedasticity tests indicated that using OLS in the model may produce biased and inefficient estimated coefficients (see Appendix Table 7 for the statistical results). The estimated damages of flooding for the affected population are obtained by multiplying the average AFD by the number of affected households, i.e. 1706, which gives US\$ 524,999.

To describe how the AFD varies under different income levels, Eq. (1) is adjusted for different income groups. Households were classified into three different income groups, i.e. low ( $\leq$ US\$ 226), middle (US\$ 226-514), and high ( $>$ US\$ 514). We used US\$ 226 value as the lowest base since it is the minimum monthly wage rate for Jakarta workers based on the Decree of the Governor of Jakarta No. 182 year 2012.

We re-estimated Eq. (1) for the three different income groups and found that DEP and ARE positively and significantly affect the AFD for all three income groups (see Tables 8, 9, 10 in "Appendix"). Table 4 shows the estimated AFD for each income group, which reveals that the highest flood damage per household occurred in the high-income group.

\subsubsection{Business sector}

Estimation by OLS for the AFD in the business sector shows the results given in Table 11 in "Appendix". DEP, DUR, TUR, and ARE have high $t$ values, which indicate that those variables are good predictors of AFD; however, variable DIS does not have a significant contribution to AFD. Using the DEP variable as an example, we can interpret that increasing one additional centimetre on the flood depth will increase the expected damage IDR 30,460 (US\$ 3.1), ceteris paribus.

The $F$-statistic takes the value of 22.08 , whereas the appropriate $5 \%$ critical value is 2.10 , and the hypothesis of all five coefficients being zero has to be rejected. All VIF values for five independent variables are less than 10, which means there is no multicollinearity. Similar to the damage function in the residential sector, heteroscedasticity is present in the business damage function, because the $\mathrm{NR}^{2}(65.75)$ is higher than $\chi^{2}(5)$ at $5 \%$ significant level (9.49). This implies that the damage function for the business sector also might be biased and inefficient. 
Table 4 Estimated actual flood damage (AFD) for the residential sector by income group

\begin{tabular}{llllc}
\hline $\begin{array}{l}\text { Income } \\
\text { group }\end{array}$ & $\begin{array}{l}\text { Damage per } \\
\text { household (US\$) }\end{array}$ & $\begin{array}{l}\text { Percentage from } \\
\text { population }(\%)(2)\end{array}$ & $\begin{array}{l}\text { Households (units) } \\
(3)=(2) * 1706\end{array}$ & $\begin{array}{l}\text { Total damage (US\$) } \\
(4)=(1) *(3)\end{array}$ \\
\hline Low & 278 & 42.0 & 717 & 199,367 \\
Middle & 297 & 45.7 & 779 & 231,166 \\
High & 449 & 12.3 & 210 & 94,269 \\
Total & & 100.0 & 1706 & 524,802 \\
\hline
\end{tabular}

Table 5 Estimated actual flood damage (AFD) in the business sector by business turnover group

\begin{tabular}{lllll}
\hline $\begin{array}{l}\text { Business } \\
\text { turnover }\end{array}$ & $\begin{array}{l}\text { Damage per } \\
\text { building (US\$) }\end{array}$ & $\begin{array}{l}\text { Percentage from } \\
\text { population }(\%)(2)\end{array}$ & $\begin{array}{l}\text { Number of business } \\
(\text { units })(3)=(2) * 816\end{array}$ & $\begin{array}{l}\text { Total damage } \\
(\text { US\$) }(4)=(1) *(3)\end{array}$ \\
\hline $\begin{array}{l}\text { Micro } \\
\text { Small- } \\
\text { medium }\end{array}$ & 465 & 49 & 400 & 186,000 \\
\begin{tabular}{l} 
Total \\
\hline
\end{tabular} & 51 & 416 & 512,928 \\
\hline
\end{tabular}

The flood damage estimation for the population is obtained by multiplying average AFD with the number of affected business units, 816, which gives US\$ 697,050. Furthermore, Eq. (1) is used to analyse AFD for two different turnover groups. The business flood damage function was analysed for two groups of businesses by turnover per year, i.e. micro (turnover $\leq$ US\$ 30,815) and small-medium (turnover between US\$ 30,815 and US\$ $513,584)$. For both models, DEP, DUR, and TUR positively and significantly influence the AFD (see Tables 12, 13 in "Appendix"). Furthermore, we calculated the total damages for each group by multiplying the coefficient of each independent variable with the means of the independent variables in each model. Table 5 indicates that the flood damage per business in the "small-medium group" is 2.6 times higher than that in the "micro-group".

Figure 2 shows the relationship between flood depth and flood damage. Note that the flood depth is only one of the five variables that were used to explain the AFD. Therefore, these scatter plots just indicate a small part of the relations in the full model, other things being equal.
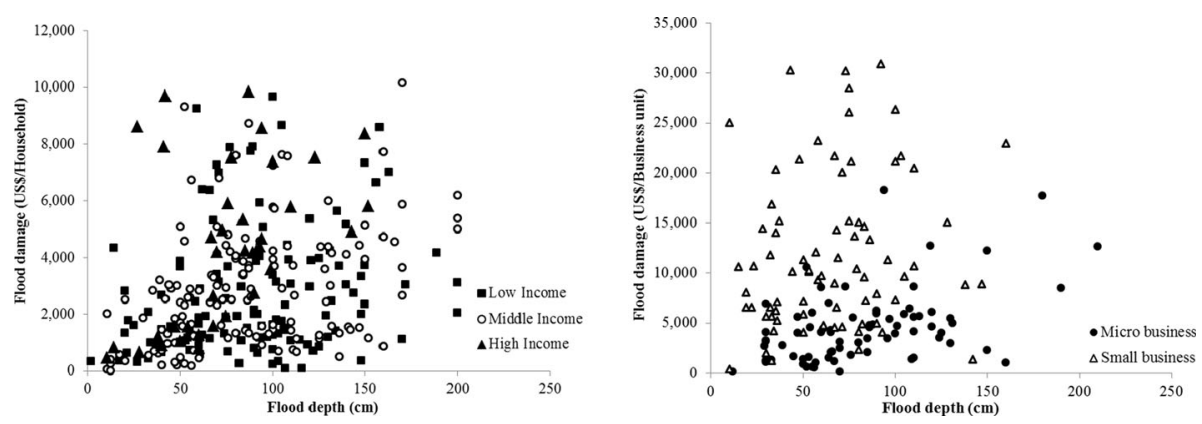

Fig. 2 Relationship between depth and flood damage in residential sector (left) and business sector (right) 


\subsection{Comparison of flood damage estimations by survey and by damage scanner}

The daily rainfall intensity from 15 to 18 January 2013 was recorded in the Pondok Betung weather station as follows: 94, 27, 59, and $76.5 \mathrm{~mm} /$ day. Therefore, the accumulated rainfall intensity during those four days was $256.5 \mathrm{~mm}$, which is the equivalent of 30-year flood return period (FRP). To simulate the 30-year flood risk, an interpolation of damage maps of 25- and 50-year FRPs is masked using the Jakarta districts boundary map.

The 30-year FRP damage map was overlaid with the survey areas to see the locations with land-use classes for the residential sector (high-density urban village) and the small and medium business sector (business and commercial). The simulated 30-year FRP most represented the survey. The natural logarithmic function produces the flood damage model as follows:

$$
Y=-353,230 \ln x+91,745
$$

where $Y$ represents the flood damage (US\$ thousand) and $x$ represents the exceedance probability. The model shows $R^{2}=0.97$. The workshop estimated the maximum damage value at US\$155,400/ha for residential sector or US\$ 930 per household (assuming that the standard house area is $60 \mathrm{~m}^{2}$ per house), and US\$517,900/ha for business sector or US\$ 5179 per business unit (assuming that the standard business unit area is $100 \mathrm{~m}^{2}$ per building). Figure 3 shows the vulnerability curves for the two sectors, and Fig. 4 shows the flood damage curve under different exceedance probabilities.

The resulting clips taken using damage scanner show over six districts in the survey areas and the 760 inundated cells (190 ha). Total direct flood damage cost is estimated at US\$ 18.2 million over 12 land-use classes. Furthermore, if the total damage is further analysed using land-use classes that were used in the survey approach, the total flood damage cost is US\$ 10.5 million, in which the residential sector damage is US\$ 1,318,235 and commercial and business is US\$ 9,248,201. Figure 5 shows an illustration of flood damage in Jakarta under the 50-year flood return period scenario. The grey and light blue areas indicate the survey areas.

The flood damage resulted by the two approaches is shown in Table 6. The estimated damage according to damage scanner is higher than the survey approach, in which the damage estimates differed by about a factor of 2.5 for the residential sector and 13 for the business sector.
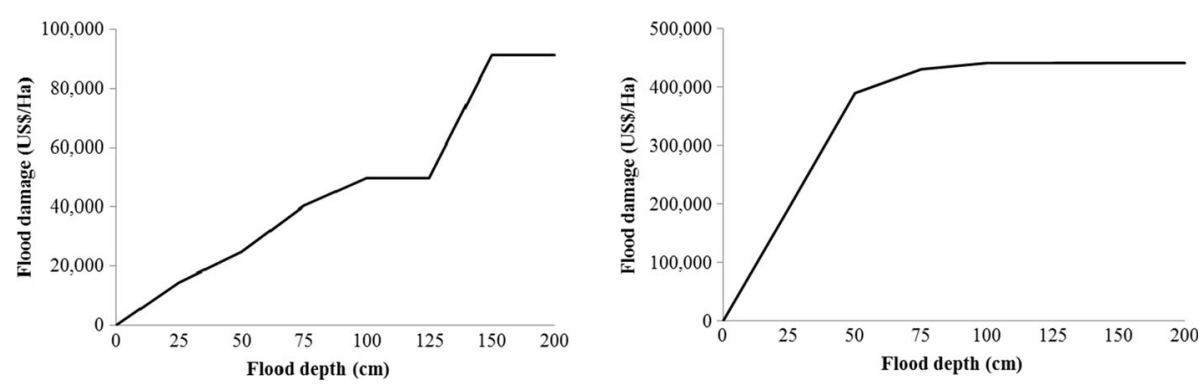

Fig. 3 Vulnerability curves for residential sector (left) and business sector (right) 
Fig. 4 Flood damage in Jakarta under different exceedance probabilities in the damage scanner

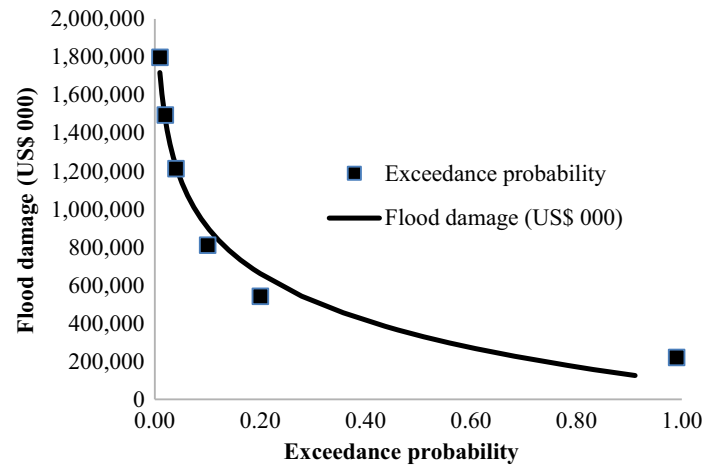

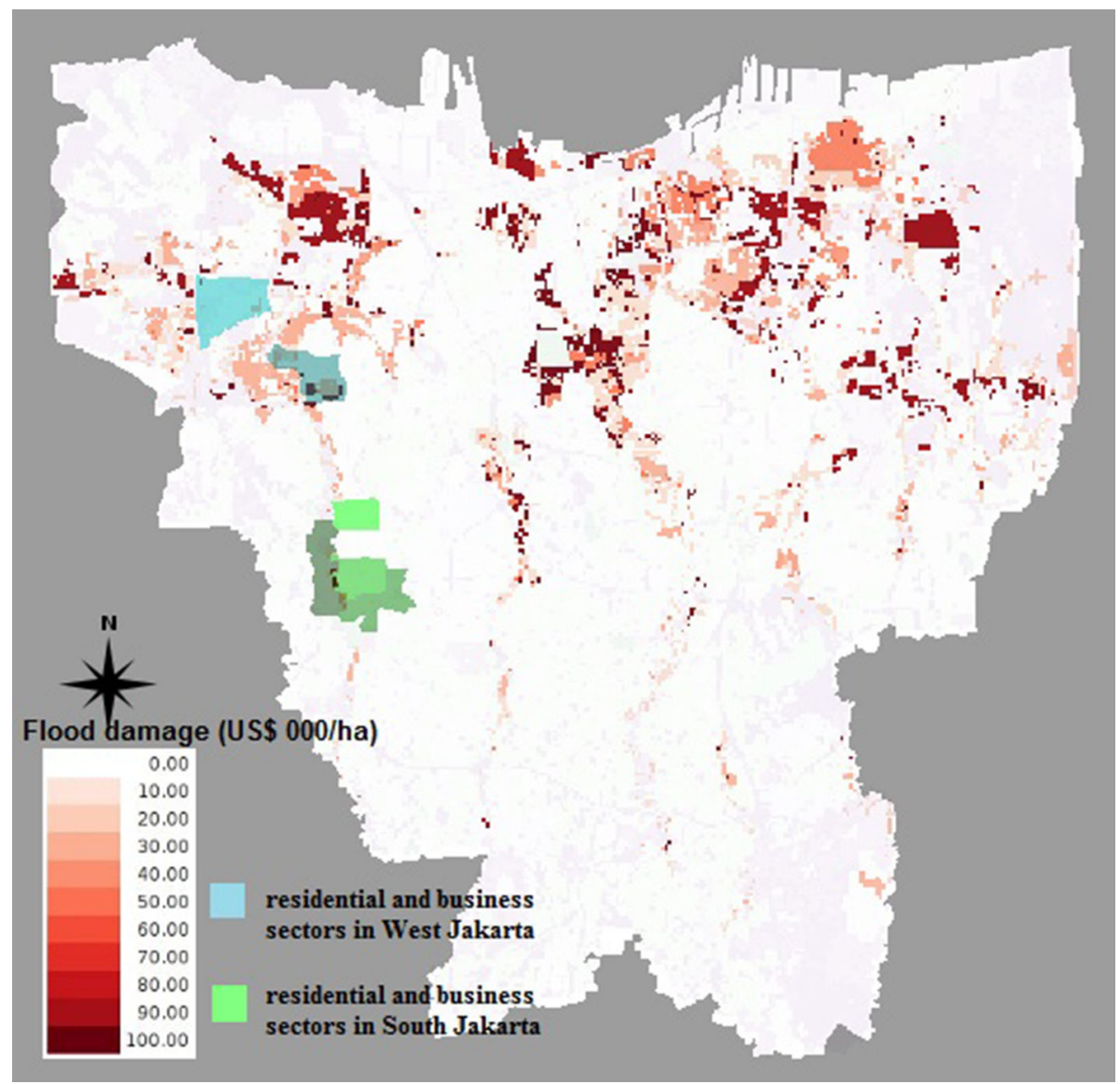

Fig. 5 Jakarta flood risk map under a 50-year flood return period 
Table 6 Estimated flood damage cost between 17 and 19 January 2013 under survey and damage scanner

\begin{tabular}{lll}
\hline Sector & Flood damages (US\$) & \\
\cline { 2 - 3 } & Survey & Damage scanner \\
\hline Residential & 524,999 & $1,318,235$ \\
Business & 697,050 & $9,248,201$ \\
\hline
\end{tabular}

\section{Discussion and conclusion}

In this paper, we compare two different approaches of estimating river flood damage in Jakarta that are based on the survey and the damage scanner. Both approaches were conducted separately. Below, we discuss the differences between the results of the two approaches.

The regression analysis from the survey data showed significant relationships among flood characteristics, socio-economic factors, and flood damage, but only a fraction of the damages could be explained by the variables included in the model. Similar to Thieken et al. (2005) and Islam (1997), this study showed that depth, duration, income, and house area are positively correlated with the extent of flood damage in the residential sector. Nevertheless, the $R^{2}$ for the residential damage function was only 0.26. Earlier studies also found low $R^{2}$ for residential damage function, e.g. 0.25 (Islam 1997) and 0.35 (Pistrika and Jonkman 2010).

Our surveys were conducted in a small area, and the reported flood damage did not present a statistically significant relationship with flood depth. Similarly, Pistrika and Jonkman (2010) found that there is no strong one-to-one relationship between depth and flood damage for stage-damage function developed for small cluster of buildings. Flood depth by itself cannot explain the damages, unless other factors, e.g. duration, contamination, and velocity, are involved (Middelmann-Fernandes 2010; Pistrika and Jonkman 2010). However, in our study, contamination and velocity were beyond the scope of the study, because those data are not available. Furthermore, a large part of the damages may be independent of the flood depth once a certain threshold of flooding has been passed and this may explain why flood depth is not significant.

In the business sector, depth, duration, daily turnover, and business area are positively correlated with the damage. This result corresponds with Islam (1997) and Kreibich et al. (2010). The regression analysis showed that the relationship between flood characteristics and flood damage was moderate with $R^{2} 0.43$. As comparison, a previous study conducted by Tang et al. (1992) showed that depth is a significant factor for commercial flood damage with $R^{2}$ 0.9. Tang et al. (1992), however, used a bigger sample which included 951 cells for the commercial sector.

The relatively low $R^{2}$ values obtained in our study may imply that the regression method is not suitable or there is no strong relationship between the variables. We applied a traditional regression model to develop flood damage functions as employed by previous studies (e.g. Appelbaum 1985; Gissing and Blong 2004; Islam 1997; Tang et al. 1992), and the scope of our survey was limited because of this traditional set-up. Merz et al. (2013) found that applying decision tree technique in selecting damage influence variables and in deriving multivariate flood damage models outperform the traditional flood damage models. Decision tree analysis is indeed promising, but it needs large data sets to identify complex relationships. Compared to Merz et al. (2013) who employed 28 predictor 
variables obtained by 2158 interviews, our data set only consists of 5 variables that focused on flood characteristics and socio-economic factors obtained by 450 interviews. For further research, we recommend to consider the decision tree analysis already from the design phase of the research project and to design the survey accordingly.

There are large differences in outcomes between the survey results (focussing on actual damages) and the damage scanner results (focussing on flood damage modelling), which is also found by previous studies. For example, Jongman et al. (2012) showed that reported flood damage was higher than flood damage estimation based on seven flood damage models. Chatterton et al. (2012) found the damage estimation by two different flood damage models for residential and commercial sectors in UK differed by a factor of about $5-6$.

The following causes explain the differences in the results from the two approaches. First, both approaches applied different ways in obtaining flood damage data and in defining the maximum flood damage per object. The survey directly collected the damage data from the samples that really were affected by flooding, while the damage scanner represents an estimation of the damage as seen by experts. Therefore, the survey was used to create an empirical flood model, while the damage scanner was used as a synthetic model (Jongman et al. 2012; Merz et al. 2010). In detail, the survey defined the maximum damage per object as the average of total damage that is incurred by houses and micro- as well as small business units located in slump areas of Jakarta. Particularly, the survey might underestimate the flood damages in the business sector, because it entailed some difficulties in interviewing large business managers, since they often refused to give detailed information. Nonetheless, the survey conducted detailed investigation per unit sample by using depreciation in assessing the structure and contents that were exposed to the flood, and by including the reduction in the damages as a result of the early flood warning and evacuation. The damage scanner defined the maximum damage per object as the expected maximum damage corresponding with several depth scenarios that are generally incurred by houses and big business located in Jakarta. It assumed a uniform building distribution, and the assessment did not consider depreciation and damage reduction effects. Based on our survey, valuing structure and content with depreciation value significantly produced lower values (about 10-20\%).

Second, the survey approach used the micro-scale (local scale), while the damage scanner approach used the meso-scale (regional scale). The survey produced an actual and detailed estimation, but it is labour-intensive especially for a large-scale study. Meanwhile, the damage scanner gave a more global estimate of the potential flood damage in Jakarta, but the calculations tend to be less accurate at the detailed level.

Third, uncertainties are present in both the survey and the damage scanner approaches. Following Wagenaar et al. (2016), uncertainties in the survey arise because flood damage was assessed based on only one single event and limited to certain ranges of depth and duration. In the damage scanner model, uncertainties appear in the construction of damage curve, the asset values associated with the curve and difference in methodological framework (Jongman et al. 2012; Merz et al. 2010; Wagenaar et al. 2016). In the damage scanner, aleatory uncertainty occurs because it used average data in valuing the maximum damage per object, assumed a uniform damage per object in each land-use class and defined expected damage by expert judgement with artificial depth scenarios. These factors lead to potential errors in the damage curve. To reduce this uncertainty, the average between different functions could be use as damage function (Wagenaar et al. 2016). Additionally, Pistrika and Jonkman (2010) found that significant uncertainty arises in damage curves when the curves are applied in small case study areas. 
The hazard map input of the damage scanner could be a possible explanation for the differences found between the survey and the damage scanner results. The depths obtained by the survey are represented at a different spatial scale from the depths that are represented by the hazard map. The survey samples were not designed to represent inundation at the spatial scale of the pluvial flood model that plays a role in the damage scanner, but has been based on random sampling for each village included in the study. The survey was designed to obtain a spatial damage map within an administrative scale from a socioeconomics point of view. Meanwhile, the SOBEK model was designed to produce spatial inundation within the Pesanggrahan catchment at a different spatial scale. This can be seen as a limitation of the SOBEK hydrology model (Deltares 2012) in producing the hazard map because the spatial resolution is too aggregated.

Mapping the results of the two approaches can be used to learn more about what contribution the hazard map has to the difference found between the two approaches, but this can only be done if the spatial scales are sufficiently similar. Unfortunately, we could not develop a detailed damage map from the survey. Since the damage scanner employs aggregated land-use data instead of individual units, we suggest for future research that the survey results can be used to improve the accuracy of the damage scanner model.

Finally, the real damage information has a greater accuracy than synthetic data (Gissing and Blong 2004), but we are also aware of the need to make assessments for larger areas in Jakarta. For further research, we recommend to also use decision tree analysis as used in Merz et al. (2013) and to design the surveys accordingly. We tend to agree with Middelmann-Fernandes (2010) and Wagenaar et al. (2016), who emphasized the consideration of multiple methods in assessing flood damage. Thus, a combination of a damage assessment based on survey and flood model based on expert assessment such as damage scanner provides a better picture of flood damage in a flooding-prone area.

Acknowledgements This research was carried out with the aid of a grant from the Economy and Environment Program for Southeast Asia of WorldFish (PCO13-0308-012) and the Dutch research programme Knowledge for Climate and Delta Alliance Jakarta Climate Adaptation Tools research project (HSINT02a).

Open Access This article is distributed under the terms of the Creative Commons Attribution 4.0 International License (http://creativecommons.org/licenses/by/4.0/), which permits unrestricted use, distribution, and reproduction in any medium, provided you give appropriate credit to the original author(s) and the source, provide a link to the Creative Commons license, and indicate if changes were made.

\section{Appendix}

See Tables 7, 8, 9, 10, 11, 12, and 13 . 
Table 7 STATA output for estimating flood damage function, multicollinearity test, and heteroscedasticity test in residential sector

\begin{tabular}{rrrr} 
Source | & SS & df & MS \\
Model | & 409906773 & 5 & 81981354.6 \\
Residual | $1.1904 e+09$ & 294 & 4048948.95 \\
- & \\
\hline Total | & $1.6003 e+09$ & 299 & 5352166.43
\end{tabular}

\begin{tabular}{|c|c|c|c|c|c|c|c|}
\hline $\mathrm{AED}$ & I & Coef. & std. Err. & $t$ & $P>|t|$ & [95\% Conf. & Interval] \\
\hline & & & & & & & \\
\hline $\begin{array}{l}\text { dep } \\
\text { dur }\end{array}$ & $\begin{array}{l}1 \\
1\end{array}$ & $\begin{array}{l}13.03926 \\
4.473057\end{array}$ & $\begin{array}{l}3.237011 \\
2.552958\end{array}$ & $\begin{array}{l}4.03 \\
1.75\end{array}$ & $\begin{array}{l}0.000 \\
0.081\end{array}$ & $\begin{array}{r}6.668614 \\
-.5513312\end{array}$ & $\begin{array}{l}19.40992 \\
9.497446\end{array}$ \\
\hline dis & 1 & 2.65409 & 1.828448 & 1.45 & 0.148 & -.9444159 & 6.252595 \\
\hline inc & 1 & .1967721 & .0366812 & 5.36 & 0.000 & .1245812 & .2689631 \\
\hline are & 1 & 7.961585 & 1.762233 & 4.52 & 0.000 & 4.493394 & 11.42978 \\
\hline _cons & I & -14.3507 & 358.5665 & -0.04 & 0.968 & -720.0331 & 691.3317 \\
\hline
\end{tabular}

$\begin{array}{rrr}\text { Variable | } & \text { VIF } & 1 / \text { VIF } \\ \text { dep | } & 1.35 & 0.741247 \\ \text { dur | } & 1.30 & 0.767737 \\ \text { are | } & 1.08 & 0.927431 \\ \text { inc | } & 1.07 & 0.938577 \\ \text { dis | } & 1.05 & 0.950729 \\ \text { Mean VIF | } & 1.17 & \end{array}$

White's test for Ho: homoskedasticity against Ha: unrestricted heteroskedasticity

$\begin{array}{lll}\text { chi2 (20) } & = & 27.17 \\ \text { Prob }>\text { chi2 } & = & 0.1306\end{array}$

Cameron \& Trivedi's decomposition of IM-test

\begin{tabular}{|c|c|c|c|}
\hline Source I & chi2 & df & $\mathrm{p}$ \\
\hline \multicolumn{4}{|c|}{ 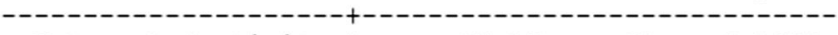 } \\
\hline Heteroskedasticity | & 27.17 & 20 & 0.1306 \\
\hline Skewness I & 22.72 & 5 & 0.0004 \\
\hline Kurtosis I & 7.71 & 1 & 0.0055 \\
\hline \multicolumn{4}{|c|}{ 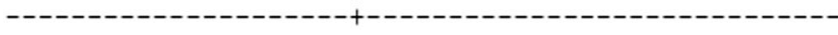 } \\
\hline Total | & 57.59 & 26 & 0.0004 \\
\hline
\end{tabular}

$\begin{array}{llr}\text { Number of obs } & = & 300 \\ \text { F } 5, \quad 294) & = & 20.25 \\ \text { Prob }>\text { F } & = & 0.0000 \\ \text { R-squared } & = & 0.2561 \\ \text { Adj R-squared } & = & 0.2435 \\ \text { Root MSE } & = & 2012.2\end{array}$


Table 8 STATA output for estimating flood damage function in low-income residential sector

\begin{tabular}{|c|c|c|c|c|c|c|}
\hline Source I & sS & $d f$ & MS & Number of obs & $=$ & 125 \\
\hline & & & & $F(5$, & $=$ & 3.52 \\
\hline Model I & 79522374.6 & 5 & 15904474.9 & Prob $>F$ & $=$ & 0.0053 \\
\hline Residual | & 537167094 & 119 & 4514009.19 & R-squared & $=$ & 0.1290 \\
\hline 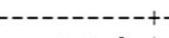 & & $\cdots$ & ----------- & Adj R-squared & $=$ & 0.0924 \\
\hline Total | & 616689468 & 124 & 4973302.17 & Root MSE & $=$ & 2124.6 \\
\hline
\end{tabular}

\begin{tabular}{|c|c|c|c|c|c|c|}
\hline AFD & Coef. & Std. Err. & $t$ & $P>|t|$ & [95\% Conf. & Interval] \\
\hline dep & 10.95329 & 5.279813 & 2.07 & 0.040 & .4987316 & 21.40785 \\
\hline dur & -.4213087 & 3.967084 & -0.11 & 0.916 & -8.276531 & 7.433914 \\
\hline dis & 4.615639 & 2.94367 & 1.57 & 0.120 & -1.213122 & 10.4444 \\
\hline inc & -.4368561 & .4308509 & -1.01 & 0.313 & -1.289984 & .4162717 \\
\hline are & 11.81916 & 4.808209 & 2.46 & 0.015 & 2.298428 & 21.3399 \\
\hline cons & 1388.445 & 907.6645 & 1.53 & 0.129 & -408.8212 & 3185.712 \\
\hline
\end{tabular}

Table 9 STATA output for estimating flood damage function in middle-income residential sector

\begin{tabular}{rrrr} 
Source | & SS & df & \multicolumn{1}{c}{ MS } \\
\hline Model | & 171260893 & 5 & 34252178.6 \\
Residual | & 438661911 & 132 & 3323196.3 \\
\hline Total | & 609922805 & 137 & 4451991.27
\end{tabular}

$\begin{array}{llr}\text { Number of obs } & = & 138 \\ \mathrm{~F}(\mathrm{~S}, 132) & =10.31 \\ \text { Prob }>\text { F } & = & 0.0000 \\ \text { R-squared } & = & 0.2808 \\ \text { Adj R-squared } & = & 0.2535 \\ \text { Root MSE } & = & 1823\end{array}$

\begin{tabular}{|c|c|c|c|c|c|c|}
\hline AFD & Coef. & Std. Err. & $t$ & $P>|t|$ & [95\% Conf. & Interval] \\
\hline dep & 11.92706 & 4.262985 & 2.80 & 0.006 & 3.494456 & 20.35967 \\
\hline dur & 9.469953 & 3.464846 & 2.73 & 0.007 & 2.616145 & 16.32376 \\
\hline dis & 2.662335 & 2.468928 & 1.08 & 0.283 & -2.221448 & 7.546117 \\
\hline inc & .4310882 & .218537 & 1.97 & 0.051 & -.0011997 & .8633761 \\
\hline are & 6.323553 & 2.376223 & 2.66 & 0.009 & 1.62315 & 11.02396 \\
\hline _cons & -1108.882 & 836.4048 & -1.33 & 0.187 & -2763.373 & 545.6092 \\
\hline
\end{tabular}

Table 10 STATA output for estimating flood damage function in high-income residential sector

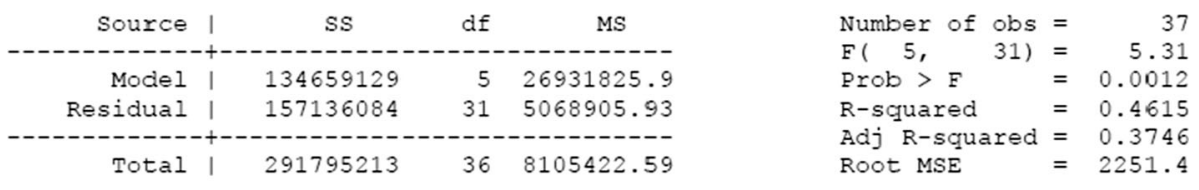

\begin{tabular}{|c|c|c|c|c|c|c|}
\hline AFD I & Coef. & Std. Err. & t & $P>|t|$ & [95\% Conf. & Interval] \\
\hline $\begin{array}{ll}\text { dep } & \text { | } \\
\text { dur } & \text { I } \\
\text { dis } & \text { I }\end{array}$ & $\begin{array}{r}30.52812 \\
7.122202 \\
-1.408446\end{array}$ & $\begin{array}{l}12.81071 \\
11.29376 \\
6.788739\end{array}$ & $\begin{array}{r}2.38 \\
0.63 \\
-0.21\end{array}$ & $\begin{array}{l}0.023 \\
0.533 \\
0.837\end{array}$ & $\begin{array}{r}4.400497 \\
-15.91158 \\
-15.25417\end{array}$ & $\begin{array}{l}56.65574 \\
30.15598 \\
12.43728\end{array}$ \\
\hline \begin{tabular}{r|} 
inc \\
are \\
cons
\end{tabular} & $\begin{array}{r}.2158973 \\
7.665146 \\
-1408.86\end{array}$ & $\begin{array}{l}.0768904 \\
3.348846 \\
1413.429\end{array}$ & $\begin{array}{r}2.81 \\
2.29 \\
-1.00\end{array}$ & $\begin{array}{l}0.009 \\
0.029 \\
0.327\end{array}$ & $\begin{array}{r}.0590784 \\
.8351303 \\
-4291.567\end{array}$ & $\begin{array}{l}.3727163 \\
14.49516 \\
1473.848\end{array}$ \\
\hline
\end{tabular}


Table 11 STATA output for estimating flood damage function, multicollinearity test and heteroscedasticity test in business sector

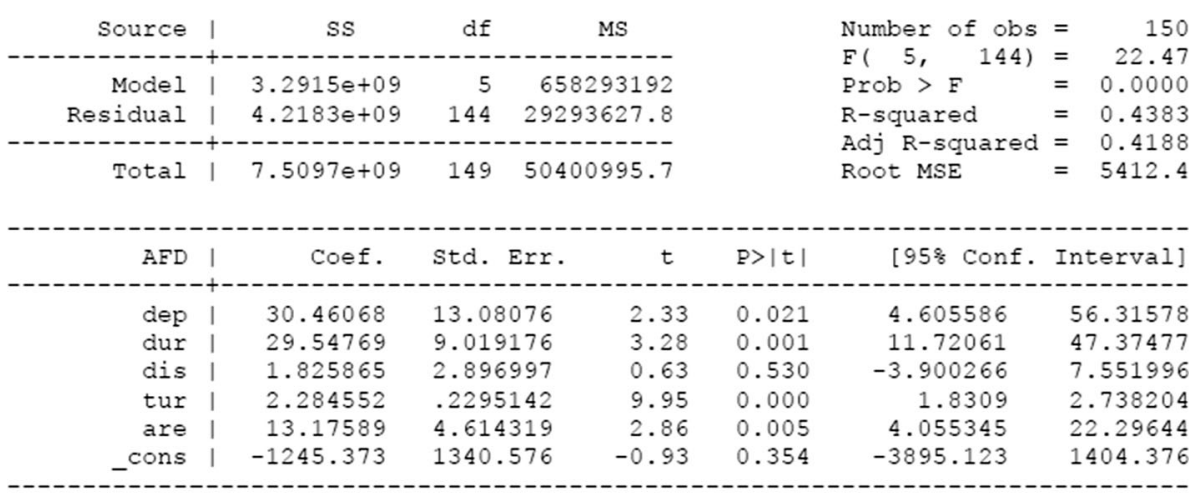

$\begin{array}{rrr}\text { Variable | } & \text { VIF } & 1 / \text { VIF } \\ \text { dur | } & 1.28 & 0.780258 \\ \text { dep | } & 1.25 & 0.801639 \\ \text { dis | } & 1.18 & 0.850134 \\ \text { are | } & 1.05 & 0.954844 \\ -0.02 & 0.977558 \\ \text { Mean VIF | } & 1.16 & \end{array}$

White's test for Ho: homoskedasticity against $\mathrm{Ha}$ : unrestricted heteroskedasticity

$\begin{array}{llr}\operatorname{chi}(20) & 49.46 \\ \text { Prob }>\text { chi2 } & =0.0003\end{array}$

Cameron \& Trivedi's decomposition of IM-test

\begin{tabular}{|c|c|c|c|}
\hline Source | & chi2 & $d f$ & $\mathrm{p}$ \\
\hline \multicolumn{4}{|c|}{ - - - - - - - - - - - - - - - } \\
\hline Heteroskedasticity | & 49.46 & 20 & 0.0003 \\
\hline Skewness | & 6.99 & 5 & 0.2211 \\
\hline Kurtosis | & 4.40 & 1 & 0.0359 \\
\hline \multicolumn{4}{|c|}{ 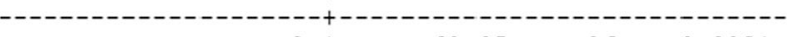 } \\
\hline Total | & 60.85 & 26 & 0.0001 \\
\hline
\end{tabular}


Table 12 STATA output for estimating flood damage function in micro-business sector

\begin{tabular}{|c|c|c|c|}
\hline Source I & sS & $d f$ & MS \\
\hline $\begin{array}{r}\text { Model } \\
\text { Residual }\end{array}$ & $\begin{array}{l}361072171 \\
607182946\end{array}$ & $\begin{array}{r}5 \\
68\end{array}$ & $\begin{array}{l}72214434.2 \\
8929160.97\end{array}$ \\
\hline-+ & --- & - & $---1--1$ \\
\hline Total | & 968255117 & 73 & 13263768.7 \\
\hline
\end{tabular}

$\begin{array}{llr}\text { Number of obs } & & 74 \\ \text { F } 5, \quad 68) & = & 8.09 \\ \text { Prob }>\text { F } & =0000 \\ \text { R-squared } & =0.3729 \\ \text { Adj R-squared } & =0.3268 \\ \text { Root MSE } & =2988.2\end{array}$

\begin{tabular}{|c|c|c|c|c|c|c|}
\hline $\mathrm{AFD}$ & Coef. & Std. Err. & t & $P>|t|$ & [95\% Conf. & Interval] \\
\hline dep & 30.81265 & 9.493503 & 3.25 & 0.002 & 11.86866 & 49.75664 \\
\hline dur & 18.98813 & 6.458346 & 2.94 & 0.004 & 6.100697 & 31.87555 \\
\hline dis & 1.557442 & 2.104255 & 0.74 & 0.462 & -2.641534 & 5.756419 \\
\hline tur & 2.711482 & 1.671413 & 1.62 & 0.109 & -.6237697 & 6.046734 \\
\hline are & 20.13589 & 11.23525 & 1.79 & 0.078 & -2.283698 & 42.55547 \\
\hline cons & -1760.934 & 1151.59 & -1.53 & 0.131 & -4058.895 & 537.0274 \\
\hline
\end{tabular}

Table 13 STATA output for estimating flood damage function in small business sector

\begin{tabular}{|c|c|c|c|c|c|c|}
\hline Source I & sS & \multirow{2}{*}{\multicolumn{3}{|c|}{ MS }} & \multirow{2}{*}{\multicolumn{2}{|c|}{ 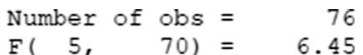 }} \\
\hline------+ & --------- & & & & & \\
\hline Model I & $1.4019 e+09$ & 28 & 80345 & & Prob $>F$ & 0.0001 \\
\hline Residual | & $3.0428 e+09$ & 434 & 749.4 & & $\mathrm{R}$-squared & 0.3154 \\
\hline---+ & --- & -- & -- & & Adj R-squared & 0.2665 \\
\hline Total I & $4.4447 e+09$ & 592 & 855.7 & & Root MSE & 6593.1 \\
\hline AFD I & Coef. & Std. Err. & $t$ & $P>|t|$ & :95\% Conf. & Interval] \\
\hline dep 1 & 42.42023 & 24.76554 & 1.71 & 0.091 & $-6 \quad 973088$ & 91.81355 \\
\hline dur | & 46.28122 & 18.1179 & 2.55 & 0.013 & 10.1462 & 82.41624 \\
\hline dis 1 & 3.310014 & 5.796919 & 0.57 & 0.570 & -8.251577 & 14.8716 \\
\hline tur 1 & 1.80069 & .3687375 & 4.88 & 0.000 & 1.065266 & 2.536114 \\
\hline are 1 & 24.95858 & 11.82158 & 2.11 & 0.038 & 1.381168 & 48.53598 \\
\hline cons I & -877.6077 & 2584.325 & -0.34 & 0.735 & -6031.882 & 4276.666 \\
\hline
\end{tabular}

\section{References}

Appelbaum SJ (1985) Determination of urban flood damages. J Water Resour Plan Manag 111:269-283

BAPPENAS (2007) Laporan Perkiraan Kerusakan dan Kerugian Pasca Bencana Banjir Awal Februari 2007 di Wilayah Jabodetabek (Jakarta, Bogor, Depok, Tangerang, dan Bekasi). Badan Perencanaan Pembangunan Nasional (BAPPENAS) Indonesia, Jakarta (in Bahasa)

BMKG, KNMI (2013) Southeast Asian Climate Assessment \& Dataset (SACA\&D) project. Badan Meteorologi Klimatologi dan Geofisika (BMKG) and Royal Netherlands Meteorological Institute (KNMI). Accessed 1 Dec 2013

BPBD (2013) Kajian Kerusakan, Kerugian Dan Kebutuhan Pemulihan Dampak Bencana Banjir Jakarta Januari 2013. Badan Penanggulangan Bencana Daerah (BPBD) DKI Jakarta, Jakarta (in Bahasa)

Budiyono Y, Aerts J, Brinkman JJ, Marfai MA, Ward P (2015) Flood risk assessment for delta mega-cities: a case study of Jakarta. Nat Hazards 75:389-413. doi:10.1007/s11069-014-1327-9

Chatterton J, Penning-Rowsell EC, Priest S (2012) The many uncertainties in flood loss assessments. In: Beven K, Hall J (eds) Applied uncertainty analysis for flood risk management. Imperial College Press, London, pp 335-343

Deltares (2012) Jakarta flood management information system. FMIS and JFEWS. Towards flood early warning, planning, and design. Ministry of Public Works Indonesia, Jakarta 
Deltares (2013) Jakarta flood January 2013. Royal Embassy of the Netherlands and Ministry of Public Works Indonesia, Jakarta

Dutta D, Herath S, Musiake K (2003) A mathematical model for flood loss estimation. J Hydrol 277:24-49. doi:10.1016/S0022-1694(03)00084-2

Firman T, Surbakti IM, Idroes IC, Simarmata HA (2011) Potential climate-change related vulnerabilities in Jakarta: challenges and current status. Habitat Int 35:372-378

Gartsman B, Nooyen RV, Kolechkina A (2009) Implementation issues for total risk calculation for groups of sites. Phys Chem Earth 34:619-625. doi:10.1016/j.pce.2008.12.001

Gissing A, Blong R (2004) Accounting for variability in commercial flood damage estimation. Aust Geogr 35:209-222. doi:10.1080/0004918042000249511

Green C (2003) Handbook of water economics: principles and practice. Wiley, Chichester

Greene WH (2012) Econometric analysis, 7th edn. Prentice Hall, Upper Saddle River

Islam K (1997) The impacts of flooding and methods of assessment in urban areas of Bangladesh. Middlesex University, London

Jongman B et al (2012) Comparative flood damage model assessment: towards a European approach. Nat Hazards Earth Syst Sci 12:3733-3752. doi:10.5194/nhess-12-3733-2012

Jonkman SN, Bočkarjova M, Kok M, Bernardini P (2008) Integrated hydrodynamic and economic modelling of flood damage in the Netherlands. Ecol Econ 66:77-90

Kazama S, Sato A, Kawagoe S (2009) Evaluating the cost of flood damage based on changes in extreme rainfall in Japan. In: Sumi A, Fukushi K, Hiramatsu A (eds) Adaptation and mitigation strategies for climate change. Springer, Tokyo, pp 3-17

Kreibich H, Seifert I, Merz B, Thieken AH (2010) Development of FLEMOcs-a new model for the estimation of flood losses in the commercial sector. Hydrol Sci J 55:1302-1314. doi:10.1080/ 02626667.2010 .529815

Mays LW (2011) Water resources engineering, 2nd edn. Wiley, Hoboken

Merz B, Thieken AH, Gocht M (2007) Flood risk mapping at the local scale: concepts and challenges. Springer, Dordrecht

Merz B, Kreibich H, Schwarze R, Thieken A (2010) Review article "assessment of economic flood damage”. Nat Hazards Earth Syst Sci 10:1697-1724. doi:10.5194/nhess-10-1697-2010

Merz B, Kreibich H, Lall U (2013) Multi-variate flood damage assessment: a tree-based data-mining approach. Nat Hazards Earth Syst Sci 13:53-64. doi:10.5194/nhess-13-53-2013

Messner F, Meyer V (2007) Flood damage, vulnerability and risk perception-challenges for flood damage research. In: Schanze J, Zeman E, Marsalek J (eds) Flood risk management—hazards, vulnerability and mitigation measures, earth and environmental science, vol IV. Springer, Dordrecht, pp 149-168

Middelmann-Fernandes MH (2010) Flood damage estimation beyond stage-damage functions: an Australian example. J Flood Risk Manag 3:88-96. doi:10.1111/j.1753-318X.2009.01058.x

Pistrika AK, Jonkman SN (2010) Damage to residential buildings due to flooding of New Orleans after hurricane Katrina. Nat Hazards 54:413-434. doi:10.1007/s11069-009-9476-y

PU (2011) ATLAS: Pengamanan Pantai Jakarta. Kementerian Pekerjaan Umum (PU) Indonesia, Jakarta (in Bahasa)

Scawthorn C et al (2006) HAZUS-MH flood loss estimation methodology. II. Damage and loss assessment. Nat Hazards Rev 7:72-81. doi:10.1061/(asce)1527-6988(2006)7:2(72)

Smith DI (1981) Actual and potential flood damage: a case study for urban Lismore, NSW, Australia. Appl Geogr 1:31-39. doi:10.1016/0143-6228(81)90004-7

Smith D (1994) Flood damage estimation-a review of urban stage-damage curves and loss functions. Water S A 20:231-238

Suriya S, Mudgal BV, Nelliyat P (2012) Flood damage assessment of an urban area in Chennai, India, part I: methodology. Nat Hazards 62:149-167. doi:10.1007/s11069-011-9985-3

Tang JCS, Vongvisessomjai S, Sahasakmontri K (1992) Estimation of flood damage cost for Bangkok. Water Resour Manag 6:47-56. doi:10.1007/bf00872187

te Linde AH, Bubeck P, Dekkers JEC, de Moel H, Aerts JCJH (2011) Future flood risk estimates along the river Rhine Nat Hazards Earth. Syst Sci 11:459-473. doi:10.5194/nhess-11-459-2011

Thieken AH, Müller M, Kreibich H, Merz B (2005) Flood damage and influencing factors: New insights from the August 2002 flood in Germany. Water Resour Res 41:1-16. doi:10.1029/2005wr004177

Verbeek M (2012) A guide to modern econometrics -, 4th edn. Wiley, West Sussex

Wagenaar DJ, De Bruijn KM, Bouwer LM, De Moel H (2016) Uncertainty in flood damage estimates and its potential effect on investment decisions. Nat Hazards Earth Syst Sci 16:1-14. doi:10.5194/nhess-16-1-2016

Ward PJ, de Moel H, Aerts JCJH (2011a) How are flood risk estimates affected by the choice of returnperiods? Nat Hazards Earth Syst Sci 11:3181-3195. doi:10.5194/nhess-11-3181-2011

Ward PJ, Marfai MA, Yulianto F, Hizbaron DR, Aerts JCJH (2011b) Coastal inundation and damage exposure estimation: a case study for Jakarta. Nat Hazards 56:899-916. doi:10.1007/s11069-010-9599-1 